\title{
The impact of corporate culture on the employee's commitment at Saigon Thuong Tin commercial joint stock bank in An Giang
}

\author{
Huynh Thanh Tu ${ }^{1,2}$, Tran Minh Hieu ${ }^{1,2,3, *}$, Nguyen Diem Yen ${ }^{4}$
}

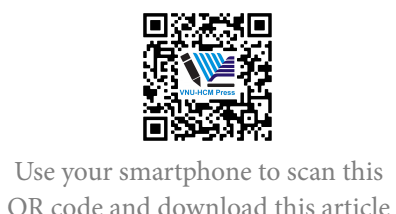

QR code and download this article

${ }^{1}$ University of Economics and Law, Ho Chi Minh City, Vietnam

${ }^{2}$ Vietnam National University, Ho Chi Minh City, Vietnam

${ }^{3}$ An Giang University, An Giang,

Vietnam

${ }^{4}$ Sai Gon Thuong Tin Commercial Joint Stock Bank, An Giang, Vietnam

\section{Correspondence}

Tran Minh Hieu, University of Economics and Law, Ho Chi Minh City, Vietnam

Vietnam National University, Ho Chi Minh City, Vietnam

An Giang University, An Giang, Vietnam

Email: tmhieu@agu.edu.vn

History

- Received: 19/12/2020

- Accepted: 11/6/2021

- Published: 23/6/2021

DOI : 10.32508/stdjelm.v5i3.741

\section{Check for updates}

Copyright

(c) VNU-HCM Press. This is an openaccess article distributed under the terms of the Creative Commons Attribution 4.0 International license.

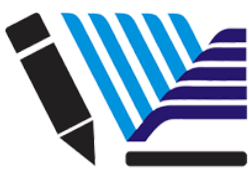

VNU-HCM Press

ABSTRACT

This study applies the scale of Ricardo \& Jolly in 1997 to measure the impact of corporate culture on the employee's commitment at Saigon Thuong Tin Commercial Joint Stock Bank in An Giang Branch (Sacombank An Giang). The study utilises Cronbach's Alpha reliability test method, Exploratory factor analysis (EFA), and Linear regression to verify and evaluate the scale. The adjustment coefficient R2 $=0.391$ means that $39.1 \%$ of the variation of the employee's commitment dependent variable is explained by 8 independent variables in the regression model. Besides, $60.9 \%$ of employee commitment variation is explained by other factors that have not been included in the research model. The results show that the elements of banking communication (Beta $=0.283$ ), teamwork (Beta $=0.260$ ), risk taking in innovation and innovation (Beta $=0.176)$, fairness and consistency in governance policy (Beta $=0.163$ ), rewards and recognition (Beta $=0.159)$ and training and development (Beta $=0.146)$ affect the commitment of employees at Sacombank in An Giang. The research results will be the basis for Sacombank An Giang to recognize the factors that affect employees' commitment to the bank, enabling the bank to plan to improve employee cohesion with the bank and develop a team of professional personnel. At the same time, the study proposes advanced governance implications of elements of corporate culture to employee's commitment in Sacombank An Giang. Building a truly strong corporate culture, enhancing employee commitment and sustainable development at Sacombank An Giang Branch is the core statement of this financial institution. ${ }^{1-27}$

Key words: Employee's commitment, Corporate culture, Sacombank An Giang

\section{INTRODUCTION}

In the era of 4.0 technology development, the continuous growth of facilities, and modern technology gradually replaces an inherent importance of human resources. The success of an enterprise in addition to advanced infrastructure and technology elements, it is impossible not to mention the great contribution of human resources including the management team and all employees. People are a major contributor to the process of achieving the goals that businesses set. To achieve that, businesses need to possess a team of enthusiastic, loyal employees who work hard for common goals and longterm commitment to the business. Corporate culture is a collection of intangible factors that play a role in connecting people-to-people relationships, greatly contributing to the success of the business. Therefore, the commitment of employees to the bank is very important, greatly influencing the success and development of Sacombank, An Giang branch in particular and Sacombank in general. Many studies show that the stronger the corporate culture, the higher the employee's commitment, employees will devote their efforts to the development of the unit and actively build and consolidate a strong and sustainable culture.

Saigon Thuong Tin Commercial Joint Stock Bank has a total of 11 branches and transaction offices located in 9 districts of An Giang province including: Long Xuyen City, Chau Doc City, Tan Chau town, Chau Phu district, Chau Thanh, Phu Tan, Cho Moi, Thoai Son, Tinh Bien, An Phu and Thoai Son. In particular, An Giang Branch was established in accordance with Official Letter 143/NHNN on May 22, 2005 of the Governor of the State Bank of Vietnam, then officially went into operation on August 3, 2005. Sacombank's personnel in An Giang province with more than 98\% are local people and most of them are young people from 1986-2000 generation. Sacombank has affirmed its position to customers through a wide range of products and services. To have the success today, human resource is the important contributing factor. Bank management needs to consider as well as have policies to improve employee engagement with the bank. Therefore, it is important to study the impact of corporate culture on employee engagement at Saigon Thuong Tin Commercial Joint Stock Bank, An Giang 
province, which is very important and must be conducted regularly so that there can be effective measurements to consolidate effective human resources. Elements of corporate culture play an important role in measuring employee commitment. What factors of corporate culture affect employee commitment and how well do these factors affect employee commitment is the goal of the study.

\section{THEORETICAL BACKGROUND}

\section{Defining Corporate culture}

According to Titiev (1959), corporate culture is a human cognitive system that helps to improve thinking and make decisions based on organizational culture ${ }^{1}$. When it comes to corporate culture, it refers to standards, beliefs, values, etc. This is formed from the process of building and developing of the business, which is recognized and implemented by employees ${ }^{2}$. According to Louis (1980), corporate culture is a set of common concepts of members, which are largely understood by the members and just like suitable for their own businesses ${ }^{3}$. These concepts are passed on to new members.

The corporate culture represents a combination of values and interdependent behaviors which are common in the enterprise and tend to be self-propagating, often in the long run ${ }^{4}$. According to Williams, Dobson \& Walters (1993) think that corporate culture is the common beliefs, values, and attitudes in enterprises ${ }^{5}$.

Corporate culture is a collection of values, beliefs that are understood and shared among the organization's members. These values help to differentiate between businesses and other businesses. At the same time, corporate culture helps employees form the attitude, working style and behavior to suit the business ${ }^{6}$.

According to Syed $\mathrm{Z}$ et al. (2011), corporate culture is a collection of meanings shared among members, helping members to manage the stars so that they are suitable for businesses ${ }^{7}$. Corporate culture including trust, rituals, practices, and imagination is built and developed over a given period of time. These things affect the overall behavior of members.

Corporate culture is one of the decisive factors for the success of an enterprise, because corporate culture is a factor that helps connect relationships between members of the business together. Maintaining and developing a culture in training and organizing personnel is really not a simple problem. At the same time, changing culture is a very difficult task for a leader. Corporate culture is seen as the way of life, the common way of thinking of each person in the business, each of whom has their own values and principles.

\section{The role of corporate culture}

Any business has its own unique cultural traits that can exist and develop in the long run. Every country or nation wants to develop and be strong, it also needs a strong culture. Corporate culture also cannot escape that category.

According to Deal and Kennedy (1982), corporate culture greatly influences the commitment of employees in the business ${ }^{8}$. Strong corporate culture allows employees to understand the goals of the business and when they work. towards corporate goals then the level of commitment to their businesses increases. Corporate culture is important in developing and maintaining employee commitment and the intensity level is often characteristic of successful organizations.

According to Saeed and Hassan (2000), corporate culture plays a major role in enterprise human resource management ${ }^{9}$. Corporate culture also greatly influences the emotions, emotions, and relationships between members of an organization.

According to Katarzyna S (2014), it is said that the role of corporate culture plays an important role in regulating employees' behaviors in enterprises, as well as the behaviors of the whole enterprise ${ }^{10}$. The corporate culture is formed based on "The idealization of common experiences". If the corporate culture is built and developed in a strong and serious manner, it will help improve the commitment of employees and the industry, promoting the affection and relationships among the members of the business karma together.

\section{Elements in corporate culture}

Corporate culture includes the beliefs and values that businesses build to adjust the behavior of employees in the business accordingly and thereby form a system of behavioral behavior in the business. According to Ricardo and Jolly (1997), organizational culture is made up of 8 factors including: (1) corporate communication, (2) training and development, (3) rewards and recognition, (4) efficiency in decision making, (5) taking risks by creativity and innovation, (6) planning and future orientation, (7) teamwork, (8) work equal and consistent in governance policies ${ }^{6}$.

In the study of Jung et al., 2009, there were identified elements of corporate culture including 4 elements of corporate culture including corporate communication, training and development, rewards and accreditation, teamwork ${ }^{11}$.

A. Bodla, Huma Ali and Naeem Ali (2013) used 10 factors to measure corporate culture including participation, collaboration, the transmission of infor- 
mation 17 , customer care, strategic direction, incentive and incentive system, control system, communication, coordination and integration ${ }^{12}$.

Business communication: is a process carried out in many different ways between superiors and subordinates, between employees in the same department or different departments together. The goal of business communication is to create a link between people to realize the common goal that the business has set earlier ${ }^{6}$.

Hypothesis H1: Banking communication positively affects employee commitment and engagement with the bank.

Training and development: is the process that allows employees to acquire new knowledge and skills to change behaviors and improve their ability to perform work. This process helps change perceptions and perspectives and can even change the relationships between members ${ }^{13}$.

Hypothesis H2: Training and development positively affects employee commitment and engagement with the bank.

Reward and recognition: is the recognition, evaluation and work that leaders need to do on a regular basis. In order to clearly and fully evaluate the dedication and achievements that employees have made in accordance with the targets set by the business. From there there are rewards as a response to their contributions ${ }^{6}$.

Rewards and recognition can be defined as salaries, bonuses and promotions awarded to outstanding performers ${ }^{14}$.

Hypothesis H3: Rewards and recognition positively influence employee commitment and engagement with the bank.

Effectiveness in decision making: Effective decision making is the result of a systematic process, with clearly defined elements, which is the processing of a separate sequence of steps ${ }^{15}$.

Hypothesis H4: Effective decision making positively affects employee commitment and engagement with the bank.

Accept creative and innovative risks: supposedly accepting the risks that may occur in the innovation of working methods, but still accepting to participate in operations, the environment and seek ways to overcome address these risks ${ }^{16}$.

Hypothesis H5: Accepting risks in innovation and improvement positively affects employee commitment and engagement with the bank.

Orientations for future plans: statements about the long-term purpose of the organization. These can be business philosophy, business principles ${ }^{6}$.
Hypothesis H6: Orientation for future plans positively affects employee commitment and commitment to the bank.

Teamwork: is a group of people working together with the same goals, members with reciprocal interaction, assigned tasks and tasks, existing in the group are clear principles. tie and dominate each member's activities, complement each other's skills, and commit to achieving common goals ${ }^{17}$.

Hypothesis H7: Teamwork positively affects employee commitment and engagement with the bank. Equity and consistency in governance policies: is the way businesses implement to make the proposed plans implemented in the most complete and effective way. This method can be performed by the basic functions or activities that an administrator can perform ${ }^{6}$.

Hypothesis H8: The fairness and consistency in governance policies positively influence employee commitment and engagement with the bank.

\section{Employee commitment \\ The concept of employee commitment}

According to Meyer and Allen (1990), employees' commitment is a psychological state that includes the characteristics of the employee-business relationship, the implications of employee engagement decisions with business ${ }^{18}$. Porter (1974) argues that employee commitment is the strength of interpersonal engagement and the involvement of such individuals in an organization $^{19}$.

The employee's commitment to the business is the employee's binding power in the implementation of one or more of the business's goals ${ }^{20}$.

Employee commitment is about determining the desire to maintain a relationship between employees and the business, building loyalty for the business. Since then, contributing to the successful implementation of the goals set out by the very best efforts for the com$\operatorname{mon}_{\operatorname{good}}{ }^{21}$.

\section{Components of employee commitment}

According to Mayer and Allen (1990), the commitment of employees to businesses has three components ${ }^{18}$ :

Affective commitment: (1) strong beliefs and acceptance of corporate values and achievements, (2) willingness to work for the business and (3) strong desire to remain a part of the business ${ }^{22}$.

Continuance commitment: something that must be done with the costs of leaving a business, this component sometimes implies a sinking commitment, because it involves Approach a business as a function of 
what employees invest in it ${ }^{23}$.

Normative commitment: an employee's obligation to continue working with a business. Employees with a high ethical commitment tend to believe that they must stay with the business regardless of what gives them.

\section{The role of employee commitment to the business}

According to Rajendran Muthuveloo and Raduan Che Rose (2005), the commitment of employees to the business has an important impact on the success of the business ${ }^{24}$. The higher the employee's commitment to engagement leads to greater loyalty, the fewer employees leave the business. Reduce training and recruitment costs for businesses.

According to research by Bhatnagar (2007), employees attached to the organization can create a competitive advantage for businesses ${ }^{25}$. A resource-based perspective suggests that an organization or organization can build a sustainable competitive advantage by creating value with its own know-how that competitors are hard to emulate. Employees attached to the organization based on these criteria will become assets and strengths that serve the organization's sustainable competitive advantage.

According to Srivastava and Bhatnagar (2008), "good management policies will strengthen employees' close connection with the organization and increase productivity $^{26}$.

The relationship between corporate culture and employee commitment

A positive organizational culture will increase the commitment and cooperation of the staff, resulting in improved corporate efficiency, unanimous attention to strategic directions and productivity. increased labor, better decision making, and high commitment at all levels of staff ${ }^{27}$.

According to Saeed and Hassan (2000), corporate culture helps maintain the cohesion between businesses and employees, creating an important competitive advantage for businesses ${ }^{9}$.

\section{RESEARCH METHODOLOGY}

\section{Research process}

Preliminary research was conducted to establish and complete the questionnaire. The study was conducted through direct surveys of employees working at Sacombank.

In-depth interviews are questions that are based on theory and practical information, and are used to find more information around research topics. After completing the questionnaire, we will check, evaluate the rationality, adjust and perfect.

Conduct a formal survey using a completed questionnaire. The collected data will be carried out for cleaning, coding and conducting analysis.

\section{Research model}

In Denison's corporate culture research model (1990), there are 4 elements: (1) Participation; (2) Consistency; (3) Adaptability; (4) Mission.

Research by Ricardo and Jolly (1997) in SAM Advanced Management Journal identifies 8 aspects of corporate culture that are appropriate to the characteristics of the business, including: (1) Communication within the organization, (2) training and development, (3) rewards and recognition, (4) Effectiveness in decision making, (5) taking risks due to creativity and innovation, (6) Orientation on Future plans, (7) Teamwork, (8) Justice and consistency in governance policies ${ }^{6}$.

In the studies of Mowday et al. (1979), there were 8 factors affecting employee engagement with the company (Figure 1): (1) working environment and conditions; (2) generous wages, (3) promotion opportunities, (4) Organizational culture, (5) A sense of ownership, (6) Flexible working hours, (7) Relationships with employers on, (8) life and work balance ${ }^{22}$.

In the study of Syed M et al. (2012) corporate culture was studied by a model with five factors, including (1) Innovation and risk taking, (2) Attention to expenditures. (3) Orientation of results, (4) Orientation of people, (5) Collective orientation ${ }^{7}$. The commitment to the organization is assessed by three factors, including (1) Emotional commitment; (2) Commitment to continue; (3) Standard commitments.

From the reference of previous studies, the author decided to develop the research model of Ricardo and Jolly (1997) including 8 elements of corporate culture affecting employees' commitment to business ${ }^{6}$ (Table 1). 


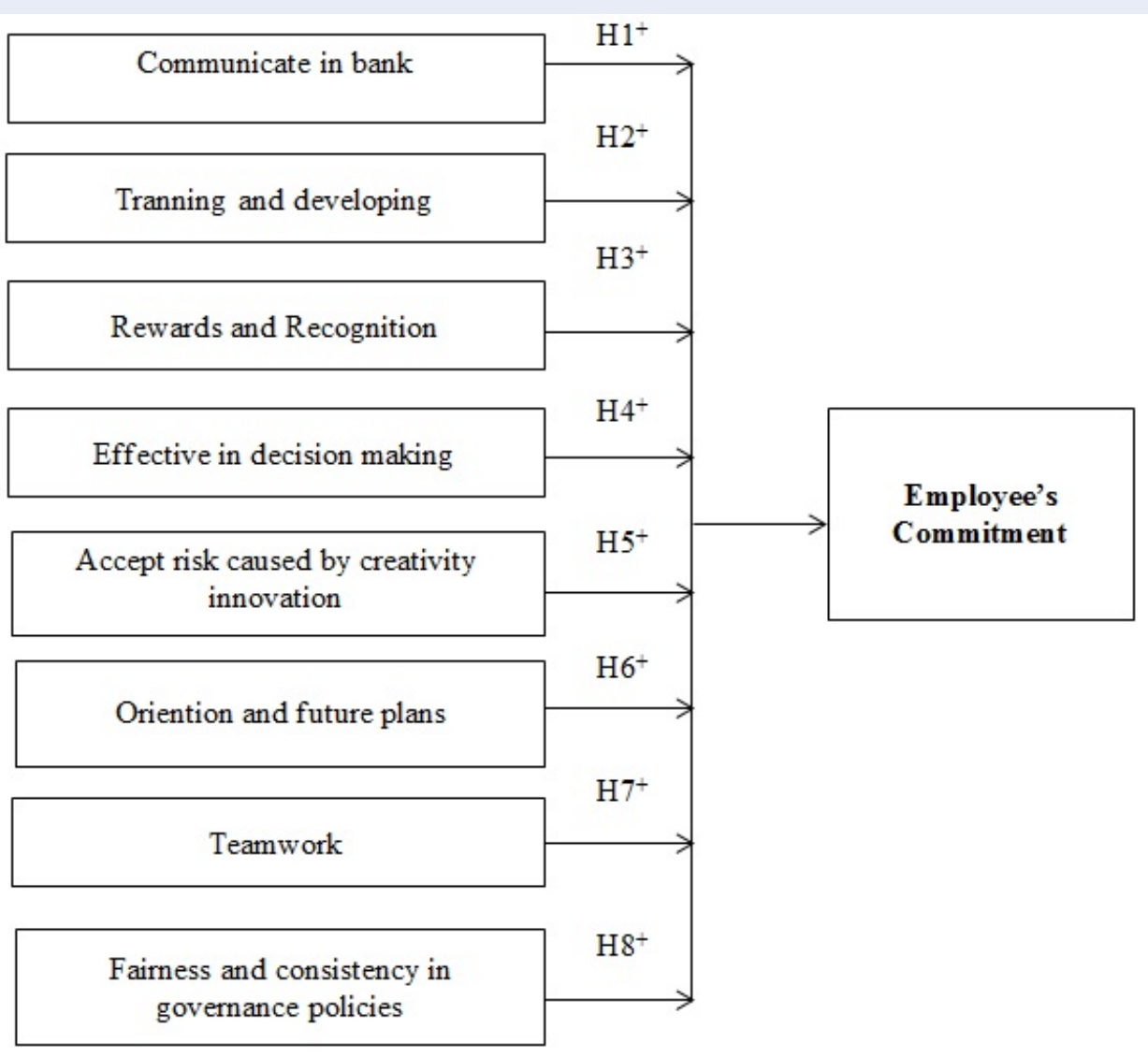

Figure 1: Research model (Source: Mowday et al. 1979) 


\section{Table 1: Interpretation of observed variables in the research model}

\begin{tabular}{|c|c|c|c|}
\hline Factors & & Observation variables & Type of scale \\
\hline \multirow[t]{5}{*}{ Communication in bank } & $\mathrm{CC} 1$ & $\begin{array}{l}\text { Staff have enough information to per- } \\
\text { form the work of each position }\end{array}$ & Liker 1 - 5 \\
\hline & CC2 & $\begin{array}{l}\text { Communication between employees is } \\
\text { encouraged }\end{array}$ & Liker $1-5$ \\
\hline & CC3 & $\begin{array}{l}\text { Organizing instructions for employees } \\
\text { on communication style }\end{array}$ & Liker $1-5$ \\
\hline & CC4 & $\begin{array}{l}\text { Superiors always listen and respect the } \\
\text { opinion of staff }\end{array}$ & Liker $1-5$ \\
\hline & CC5 & $\begin{array}{l}\text { Language regulations are always fol- } \\
\text { lowed }\end{array}$ & Liker 1 - 5 \\
\hline \multirow[t]{4}{*}{ Training and development } & TD1 & $\begin{array}{l}\text { The Bank organizes training programs } \\
\text { to improve knowledge and skills staff } \\
\text { for employees }\end{array}$ & Liker $1-5$ \\
\hline & TD2 & $\begin{array}{l}\text { Training programs organized by the } \\
\text { bank that are suitable for staff }\end{array}$ & Liker $1-5$ \\
\hline & TD3 & $\begin{array}{l}\text { Bank provides full equipment for work- } \\
\text { ing staff }\end{array}$ & Liker $1-5$ \\
\hline & TD4 & $\begin{array}{l}\text { Bank creates favorable conditions for } \\
\text { employees to advance and develop }\end{array}$ & Liker $1-5$ \\
\hline \multirow[t]{4}{*}{ Rewards and recognition } & RR1 & $\begin{array}{l}\text { The Bank recognizes the efforts and } \\
\text { achievements of employees }\end{array}$ & Liker $1-5$ \\
\hline & RR2 & $\begin{array}{l}\text { Staff receive a reward from their supe- } \\
\text { rior for their achievements }\end{array}$ & Liker $1-5$ \\
\hline & RR3 & $\begin{array}{l}\text { The Bank has rewards that are well re- } \\
\text { ceived from the staff }\end{array}$ & Liker $1-5$ \\
\hline & RR4 & Bank clearly announces bonus ranges & Liker $1-5$ \\
\hline \multirow[t]{4}{*}{ Effective in decision making } & ED1 & $\begin{array}{l}\text { Employee plans are quickly reviewed by } \\
\text { the bank }\end{array}$ & Liker $1-5$ \\
\hline & ED2 & $\begin{array}{l}\text { The Bank usually makes timely and ac- } \\
\text { curate decisions to maintain the long- } \\
\text { term development }\end{array}$ & Liker $1-5$ \\
\hline & ED3 & $\begin{array}{l}\text { The bank collects information before } \\
\text { making important decisions }\end{array}$ & Liker $1-5$ \\
\hline & ED4 & $\begin{array}{l}\text { Employees are allowed to contribute } \\
\text { opinions to the decision making of } \\
\text { leaders }\end{array}$ & Liker $1-5$ \\
\hline \multirow[t]{4}{*}{$\begin{array}{l}\text { Accept risk caused by creativ- } \\
\text { ity innovation }\end{array}$} & AR1 & $\begin{array}{l}\text { The bank accepts the innovative ideas of } \\
\text { employees }\end{array}$ & Liker $1-5$ \\
\hline & AR2 & $\begin{array}{l}\text { The Bank always encourages employees } \\
\text { to be creative, innovate working meth- } \\
\text { ods to improve the efficiency of }\end{array}$ & Liker $1-5$ \\
\hline & AR3 & $\begin{array}{l}\text { CR3 Employees are encouraged to learn } \\
\text { from the experience before }\end{array}$ & Liker $1-5$ \\
\hline & AR4 & $\begin{array}{l}\text { CR4 Reward Bank for innovative, effec- } \\
\text { tive innovation }\end{array}$ & Liker 1 - 5 \\
\hline \multirow[t]{3}{*}{ Orientations for future plans } & OF1 & The Bank develops a clear future plan & Liker $1-5$ \\
\hline & OF2 & $\begin{array}{l}\text { Bank shares specific future plans and } \\
\text { goals for each employee }\end{array}$ & Liker 1 - 5 \\
\hline & OF3 & Staff fully support the target plan & Liker $1-5$ \\
\hline
\end{tabular}


Table 1 continued

OF4 The Bank always has plans and future goals suitable to the development of businesses

Teamwork

TW1

teamwork Staff likes to work with members of the department

TW2 The members of the division are clearly assigned and work effectively

TW3 Staff always receive help from members of the same unit

TW4 Staffs always receive support and cooperation from other departments in Bank

Fairness and consistency in FC1 governance policies

management policy Staff with clear reward and promotion policies

FC2 Remuneration and punishment policies are allocated fairly

FC3 The Bank does not exist bias

FC4

The leadership team has consistently agreed on the implementation of policies for employees

Commitment of employees to

CE1 Staff is proud to be part of bank

Liker $1-5$ sticks with the bank

CE2

Employees are always making more ef-

Liker 1 - 5 forts to help the bank succeed than

CE3 The bank really gives its employees a lot of good things in the work

CE4 The employee accepts any assignment at work to continue working in banks

CE5 Staff wants to stay with for a long time
Liker $1-5$

Liker 1 - 5

Liker 1 - 5

Liker 1 - 5

Liker 1 - 5

Liker 1 - 5

Liker 1 - 5

Liker 1 - 5

Liker 1 - 5

Liker 1 - 5

Liker 1 - 5

Liker 1 - 5

(Source: Ricardo and Jolly (1997)) 


\section{R ESULTS AND DISCUSSION}

\section{Reliability test Result by Cronbach's Alpha}

The survey was conducted from February to the end of March 2020, through the distribution of direct questionnaires and google form links for employees working at Sacombank. As a result, 154 satisfactory surveys from 175 questionnaires were distributed.The data is analyzed and reported (Table 2).

Cronbach's Alpha coefficient of observed variables OF1 and OF4 is greater than 0.780

The observed TW1 has a correlation coefficient of total smaller than 0.3 and Cronbach's Alpha coefficient is greater than 0.681 .

After completing the scale test using Cronbach's Alpha coefficient, the number of observed variables remained 33 variables, remaining 8 independent variables.

\section{Results of Exploratory factor analysis (EFA)}

Cronbach's Alpha coefficient test results are used for the discovery factor analysis (EFA). After two analyzes of the results obtained from the initial 36 observed variables are grouped into 8 factors with 33 observed variables, namely:

The results of EFA for the corporate culture factors + The results of EFA - First times

Through KMO and Bartlett's tests in factor analysis showed that KMO coefficient is $0.736>0.5$ with significance level sig $=0.000$. Therefore the factors qualify for EFA analysis.

The result of the total variance explained at Eigenvalues is greater than 1 , the analysis extracted 8 groups of factors from 30 observed variables with extracted variance of $67.073 \%$ satisfactory because it is greater than $50 \%$.

The first EFA analysis showed that in the 30 observed variables all load factors were greater than 0.4 and observed variables RR1 and RR had low factor load factors, so they were removed from the model and proceeded factor analysis 2 .

+ The results of EFA - Second times

KMO and Bartlett's tests in factor analysis showed that KMO coefficient $=0.651>0.5$ with sig significance level. $=0.000$. Based on the results of the sample matrix shows that the observed variables have factor load factor $>0.45$, so it is eligible for factor analysis. Based on the results of the total variance explained at the level of Eigenvalues greater than 1, the analysis table extracted 8 groups of factors from 28 observed variables with extracted variance of $68.782 \%$ satisfactory because of greater than $50 \%$.
After 2 discovery factor analysis (EFA) results, there are 8 groups of factors extracted from the model. The first group of factors includes 4 observed variables TD3, TD1, TD4, and TD2. The second group of factors includes 5 observed variables CC4, CC5, CC3, $\mathrm{CC} 2$, and CC1. The third group of factors includes 4 observed variables AR2, AR3, AR1, and AR4. The fourth group of factors includes 4 observed variables FC3, FC4, FC1, and FC2. The fifth group of factors includes 4 observed variables ED2, ED1, ED4, ED3. The 6th group of factors includes 3 observed variables TW2, TW3, and TW4. The 7th group of factors includes 2 observed variables OF2 and OF3. The 8th group of factors includes 2 observed variables RR2, RR4 (Table 3).

The results of the factor analysis of employee engagement commitment at the bank

$\mathrm{KMO}$ and Bartlett's tests in factor analysis for employee commitment to the bank show that the KMO coefficient is 0.835 greater than 0.5 , the sig significance level. is $0.000<0.05$. Therefore, the basis of variables is correlated with each other and suitable for EFA analysis. Eigenvalue coefficient of components greater than 1, with deduction variance of $62.384 \%$ greater than $50 \%$ should meet the requirements. Factor load factor of observed variables is greater than 0.5 , thus meeting the requirements of factor analysis.

\section{Regression analysis}

The adjustment coefficient $\mathrm{R}^{2}$ means that $39.1 \%$ of employee commitment variability is explained by 8 independent variables TD, CC, AR, FC, ED, TW, OF and RR with $60.9 \%$ of the variation (Table 4 ). The employee's commitment to commitment is explained by factors that have not been included in the model.

Thus the regression equation is rewritten as follows

$\mathrm{CE}=0.283 \mathrm{CC}+0.146 \mathrm{TD}+0.159 \mathrm{RR}+0.176 \mathrm{AR}+$ $0.260 \mathrm{TW}+0.163 \mathrm{FC}$

The regression results show that the independent variables CC, TD, RR, AR, TW, FC have Beta coefficients, respectively $0.283,0.114,0.159,0.176,0.260,0.163$, all positive signs (Table 5). ositively to the commitment of the trusting staff of Saigon Thuong tin Commercial Join Stock Bank in An Giang province.

So it can be concluded that the theoretical model is suitable with the data, hypotheses $\mathrm{H} 1, \mathrm{H} 2, \mathrm{H} 3, \mathrm{H} 4$, $\mathrm{H} 7, \mathrm{H} 8$ are accepted. The results show that 6 independent variables out of 8 have significant effects on the dependent variable ( $\operatorname{sig}<0.05)$. 


\begin{tabular}{|c|c|c|c|c|c|}
\hline Factors & $\begin{array}{l}\text { Scale Mean if } \\
\text { Item Deleted }\end{array}$ & $\begin{array}{l}\text { Scale Variance if } \\
\text { Item Deleted }\end{array}$ & $\begin{array}{l}\text { Corrected Item-Total } \\
\text { Correlation }\end{array}$ & $\begin{array}{l}\text { Cronbach's Alpha if Item } \\
\text { Deleted }\end{array}$ & $\begin{array}{l}\text { Cronbach's } \\
\text { Alpha }\end{array}$ \\
\hline $\mathrm{CC} 1$ & 11.03 & 11.613 & 0.549 & 0.807 & 0.823 \\
\hline CC2 & 11.03 & 11.712 & 0.548 & 0.807 & \\
\hline $\mathrm{CC} 3$ & 11.97 & 9.901 & 0.632 & 0.786 & \\
\hline $\mathrm{CC} 4$ & 11.51 & 10.147 & 0.660 & 0.775 & \\
\hline CC5 & 11.71 & 10.509 & 0.712 & 0.761 & \\
\hline TD1 & 10.14 & 7.391 & 0.808 & 0.884 & 0.912 \\
\hline TD2 & 10.04 & 8.129 & 0.795 & 0.888 & \\
\hline TD3 & 10.09 & 7.482 & 0.818 & 0.879 & \\
\hline TD4 & 10.03 & 8.241 & 0.785 & 0.892 & \\
\hline RR1 & 10.74 & 4.246 & 0.466 & 0.612 & 0.680 \\
\hline RR2 & 10.32 & 4.571 & 0.390 & 0.661 & \\
\hline RR3 & 10.47 & 4.277 & 0.536 & 0.567 & \\
\hline RR4 & 10.44 & 4.483 & 0.463 & 0.614 & \\
\hline ED1 & 9.8 & 3.248 & 0.497 & 0.674 & 0.725 \\
\hline ED2 & 9.36 & 2.913 & 0.578 & 0.625 & \\
\hline ED3 & 9.30 & 3.374 & 0.491 & 0.678 & \\
\hline ED4 & 9.27 & 3.177 & 0.494 & 0.677 & \\
\hline AR1 & 9.92 & 5.942 & 0.575 & 0.800 & 0.816 \\
\hline AR2 & 9.73 & 5.585 & 0.722 & 0.727 & \\
\hline AR3 & 9.66 & 6.227 & 0.684 & 0.751 & \\
\hline AR4 & 9.89 & 6.177 & 0.581 & 0.794 & \\
\hline OF1 & 9.06 & 4.617 & 0.424 & 0.807 & 0.824 \\
\hline OF2 & 9.12 & 3.712 & 0.742 & 0.639 & \\
\hline OF3 & 9.10 & 3.976 & 0.735 & 0.651 & \\
\hline OF4 & 9.19 & 4.494 & 0.474 & 0.782 & \\
\hline TW1 & 11.57 & 4.482 & 0.154 & 0.800 & 0.8 \\
\hline TW2 & 11.51 & 3.271 & 0.654 & 0.493 & \\
\hline TW3 & 11.66 & 3.336 & 0.594 & 0.530 & \\
\hline TW4 & 11.68 & 3.266 & 0.525 & 0.573 & \\
\hline $\mathrm{FC} 1$ & 9.27 & 4.631 & 0.474 & 0.760 & 0.768 \\
\hline $\mathrm{FC} 2$ & 9.29 & 4.754 & 0.455 & 0.768 & \\
\hline FC3 & 9.31 & 3.795 & 0.731 & 0.619 & \\
\hline FC4 & 9.38 & 4.081 & 0.626 & 0.680 & \\
\hline CE1 & 12.89 & 13.341 & 0.687 & 0.886 & 0.895 \\
\hline CE2 & 13.02 & 13.601 & 0.727 & 0.875 & \\
\hline CE3 & 12.82 & 15.047 & 0,646 & 0.892 & \\
\hline CE4 & 12.94 & 13.258 & 0,810 & 0.856 & \\
\hline CE5 & 13.03 & 13.150 & 0,853 & 0.847 & \\
\hline
\end{tabular}




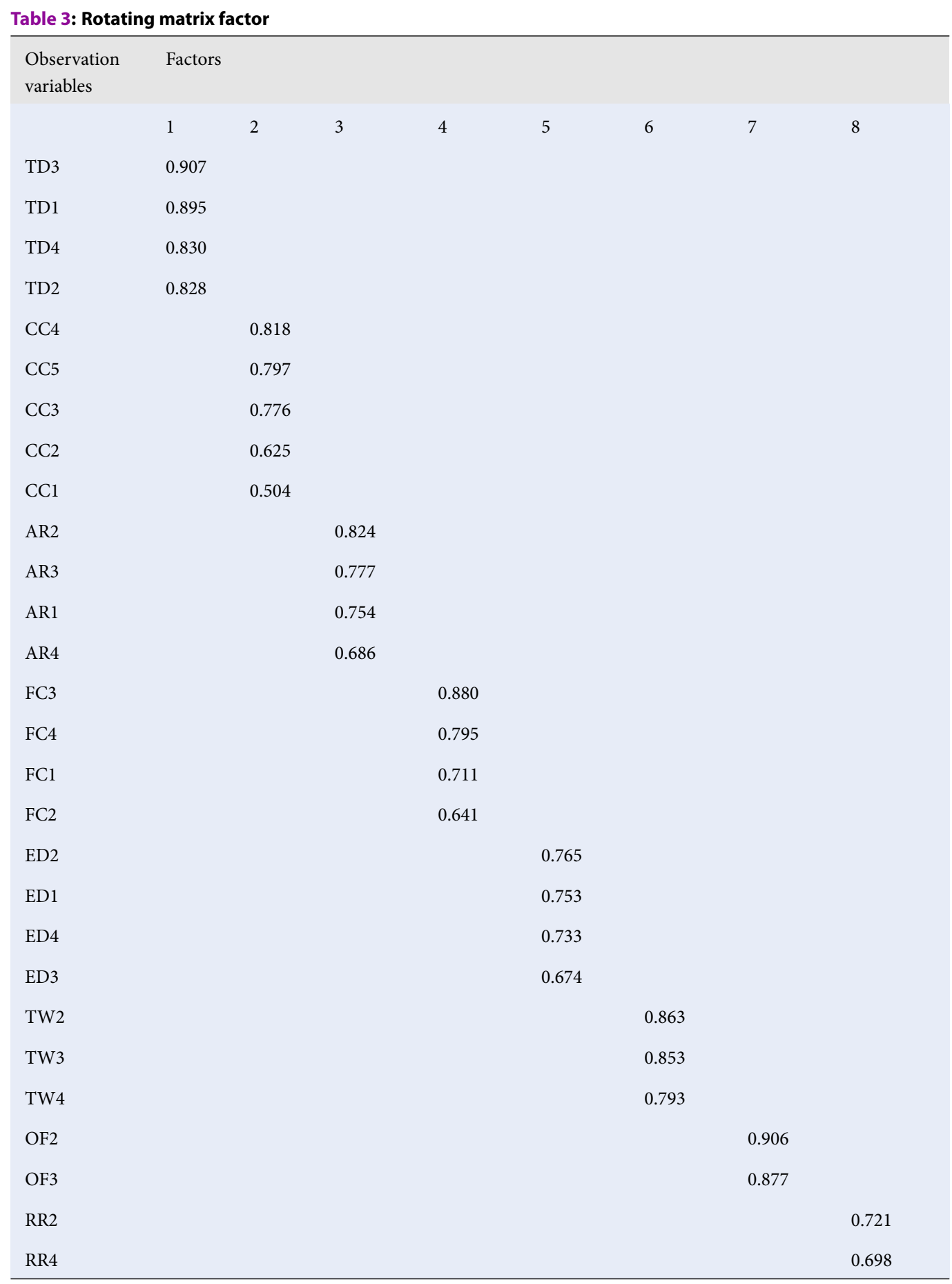

(Source: Results from data analysis)

Table 4: Summary of models

\begin{tabular}{llllll}
\hline Model & $\mathrm{R}$ & $\mathrm{R}^{2}$ & $\mathrm{R}^{2}$ adjusted & Std. Error of the Estimate & DurbinWatson \\
1 & 0.644 & 0.415 & 0.391 & 0.770 & 1.974 \\
\hline
\end{tabular}

(Source: Results from data analysis) 


\begin{tabular}{|c|c|c|c|c|c|c|c|c|c|}
\hline \multicolumn{2}{|c|}{ Model } & \multicolumn{2}{|c|}{$\begin{array}{l}\text { Unstandardized } \\
\text { cients }\end{array}$} & \multirow{2}{*}{$\begin{array}{l}\text { Coeffi- } \\
\text { ror }\end{array}$} & \multirow{2}{*}{$\begin{array}{l}\text { Standardized } \\
\text { Coefficients } \\
\text { Beta }\end{array}$} & \multirow[t]{2}{*}{$\mathrm{T}$} & \multirow[t]{2}{*}{ Sig. } & \multicolumn{2}{|c|}{ Collinearity Statistics } \\
\hline & & & Std. & & & & & Tolerance & VIF \\
\hline \multirow[t]{7}{*}{1} & (Constant) & -1.788 & 0.55 & & & -3.236 & 0,001 & & \\
\hline & $\mathrm{CC}$ & 0.348 & 0.095 & & 0.283 & 3.674 & 0,000 & 0,670 & 1,493 \\
\hline & TD & 0.156 & 0.074 & & 0.146 & 2.113 & 0,036 & 0,839 & 1,192 \\
\hline & $\mathrm{RR}$ & 0.205 & 0.092 & & 0.159 & 2.220 & 0,028 & 0,772 & 1,296 \\
\hline & $\mathrm{AR}$ & 0.219 & 0.095 & & 0.176 & 2.319 & 0,022 & 0,691 & 1,447 \\
\hline & TW & 0.363 & 0.091 & & 0.260 & 4.014 & 0,000 & 0,950 & 1,053 \\
\hline & FC & 0.242 & 0.096 & & 0.163 & 2.530 & 0,012 & 0,954 & 1,048 \\
\hline
\end{tabular}

(Source: Results from data analysis)

\section{CONCLUSION}

Through multiple regression analysis, it is shown that 6 factors in corporate culture including CC, TD, RR, $\mathrm{AR}, \mathrm{TW}$ and FC have the same directional impact on CK (Commitment commitment of employees to the bank). Considering the $\mathrm{CC}$ variable has the largest influence on employee commitment to the bank with ( $\beta$ $=0.283$ ), the TW variable has the second largest influence on employee commitment to bank ( $\beta=0.260$ ), the AR variable has the third largest influence on employee commitment to bank ( $\beta=0.176$ ), FC variable has the fourth largest impact on employee commitment. For banks ( $\beta=0.163$ ), the RR variable has the fifth largest impact on employee commitment to bank ( $\beta=0.159$ ), the TD variable has the lowest impact on engagement commitment. of employees with the bank ( $\beta=0.146)$. The results showed that 6 independent variables have significant effects on the dependent variable (sig $<0.05)$.

After determining the impact factors of corporate culture on employee engagement commitment at Saigon Thuong Tin Commercial Joint Stock Bank, An Giang province, the author continues to analyze by statistical methods to give the basis and recommendations to increase the commitment level of businesses.

In summary, the research results have achieved the research objectives, which are assessing the impact of corporate culture on employee commitment at Saigon Thuong Tin Commercial Joint Stock Bank in An Giang province. Specifically, the study identifies the factors of Corporate Culture that affect employees' commitments, the research results also show the impact of corporate culture factors on employee commitments at Sacombank An Giang. This is the basis for researching and proposing solutions to enhance employees' commitment to the impact of corporate culture factors at Sacombank An Giang

Proposing to improve the commitment to sticking with the business with the element of Communication in the bank

- The Board of Directors of Saigon Thuong Tin Commercial Joint Stock Bank needs to be more open to listening to staff contributing ideas and respecting the ideas they propose. In addition, information informed from senior to subordinate should be ensured that it is complete and accurate for each employee's job position.

- On the other hand, the leadership also needs to encourage employees among departments to always actively support each other in providing information to serve the process of work done better.

Proposing to improve commitment to sticking with businesses with teamwork

- The Management Board of Saigon Thuong Tin Commercial Joint Stock Bank needs to be proactive in organizing activities in teams and groups with a certain number of employees on holidays, New Year, the anniversary of the bank's establishment, anniversary of branch establishment, ....

- Thereby the Management Board of Saigon Thuong Tin Commercial Joint Stock Bank need to encourage employees to contribute and propose new ideas of working, and reward those which are effective in order to increase the employee's commitment to the collective as well as the employee's commitment to the bank.

Proposal to improve commitment to sticking with businesses with risk-taking element in innovation and innovation

- The Board of Directors of Saigon Thuong Tin Commercial Joint Stock Bank needs to revise the job titles that need to be changed regularly to achieve high 
efficiency in the performance of employees such as The position of a customer specialist, this position requires employees to flexibly change the way the work is done. Management should have clear plans for this creation and improvement to staff and implementation requirements.

- In addition, the board of directors also needs to organize the encouragement of employees to contribute, develop new effective work ideas and implement rewarding for development ideas. At the same time, management needs to anticipate and take preventive measures for possible risks to innovation and innovation.

Proposal to improve commitment to sticking with businesses with equity and consistency in governance policies

- The Management Board of Saigon Thuong Tin Commercial Joint Stock Bank needs to consider clearly announcing the policies of the promotion process for employees, as well as exercising fairness in rewarding and handling. management of all employees, thereby promoting the commitment of employees to the bank through the element of fairness and consistency in the governance policy.

Proposal to improve commitment to sticking with businesses with Rewards and recognition

- The Management Board of Saigon Thuong Tin Commercial Joint Stock Bank needs to consider clearly announcing the reward levels for employees who well perform the targets and plans set by the bank.

- At the same time, the bank needs to recognize the employee's contributions appropriately, and help employees feel that their dedication to the bank is totally worth. This helps promote the capacity development of employees in particular and the growth of the bank in general.

Proposing to improve the commitment to stick businesses with the element of Training and Development

- The Management Board of Saigon Thuong Tin Commercial Joint Stock Bank needs to have plans on training programs, fostering knowledge and skills as well as being really suitable for employees. , to ensure the ability to learn and apply practically to new knowledge.

- In addition, the leadership also needs to set out roasting promotion goals in order to create motivation to work and constantly strive for employee development. That will promote the efficiency in the work of employees in particular and the success of the bank in general.

Limitations and recommendations for future study In general, during the research process, the author also avoids the shortcomings. Factors of corporate culture affecting employee commitment only represent $39.1 \%$. The next research direction is at the scale of the whole Vietnamese commercial banking system to reinforce and further clarify the factors of corporate culture that affect employee commitment in the commercial banking sector.

\section{LIST OF ABBREVIATIONS}

AR : Accept risk caused by creativity innovation

CE: Commitment of employees to sticks with the bank

ED : Effective in decision making

EFA: Exploratory Factor Analysis

FC : Fairness and consistency in governance policies

$\mathbf{H}$ : Hypothesis

KMO: Kaiser-Meyer-Olkin (KMO) Test

OF: Orientations for future plans

R: regression

RR : Rewards and recognition

Sig: Significant

TW : Teamwork

VIF : Variance inflation factor

\section{ACKNOWLEDGEMENT}

The authors would like to thank the Board of Directors, and the entire staff of Sacombank An Giang for supporting the team to complete this study.

\section{DECLARATION OF CONFLICTING INTEREST}

The authors declare that they have no conflicts of inerest.

\section{AUTHOR'S COTRIBUTION}

The content of the article is studied by the authors :

- Huynh Thanh Tu: Research methods, research scales, and final review of research results.

- Tran Minh Hieu: Study the revision of the research model, write a draft of the results, and review the final results.

- Nguyen Diem Yen: Support for reviewing, surveying data, analyzing results and writing reports.

\section{REFERENCES}

1. Titiev. Introduction to cultural anthropology. New York: Henry Holt \& Co; 1995;

2. Eldrige C. A sociology of organization. London: Allen \& Unwin; 1974;Available from: https://doi.org/10.2307/2391970.

3. Louis MR. Surprise and Sense Making: What Newcomers Experience in Entering Unfamiliar Organizational Settings. Administrative Science Quarterly. 1980. 226-251;Available from: https://doi.org/10.2307/2392453.

4. Kotter JP, Heskett JL. Corporate Culture and Performance. New York: Free Press; 1992;. 
5. Williams AP, Dobson, Walters M. The Effects of Change work on Middle Managers when Implementing Organizational Change. London: IPM; 1993;Available from: https://doi.org/10. $1177 / 103841110003800307$.

6. Recardo J. Organizational culture and teams. SAM Advanced Management Journal. 1997; 62: 4-7.;.

7. Syed ZR, et al. Effects of Organizational Culture on Psychology of Employee Commitment. IEEE. 2011;Available from: https: //doi.org/10.1109/ICIEEM.2011.6035572.

8. Deal K. Human Resource Management in a Business Context. 1998;

9. Saeed H. The Influence of Corporate Culture on Organisational Commitment. 2000;.

10. Katarzyna S. The importance of organizational culture for innovation in the company. 2014;.

11. Jung T, Scott T, Davies HT, Bower P, Whalley D, McNally R, Mannion RJP. Instruments for exploring organizational cuture: $A$ review of the literature.1996; 69(6): 1087-1096;Available from: https://doi.org/10.1111/j.1540-6210.2009.02066.x.

12. Bodla HA, Naeem A. Impact Oforganizational Culture on Performance of Universities in Pakistan, Middle-East Journal of Scientific Research. 2013; 18 (9): 1313-1321;

13. Hội HV. Quản trị nhân lực trong doanh nghiệp. Hà Nội: NXB Bưu Điện; 2007;

14. Kambey, Djastuti, Suharnomo. Pengaruh budaya organisasi, gaya kepemimpinan transformasional dan sistem kompensasi terhadap komitmen organisasional dengan kepuasan kerja sebagai variabel mediasi. 2016;

15. Drucker. The Effective Executive. 1967;

16. Đỗ Tiến Long. Triết lý Kaizen và lãnh đạo doanh nghiệp. VNU Journal of Science: Economics and Business. 2010;.

17. Katzenbach S. The Décipline of Teams. Harvard Business Review. 1993;

18. Meyer J, Allen N. The measurement and antecedents of affective, continuance, and normative commitment to the organization. Journal of Occupational Psychology.1990; 63: 118;Available from: https://doi.org/10.1111/j.2044-8325.1990. tb00506.x.

19. Porter. Organizational commitment, job satisfaction, and turnover among psychiatric technicians. Journal of Applied Psychology.1974; 59(5): 603-609;Available from: https://doi. org/10.1037/h0037335.

20. Meyer JP, Herscovitch L. Commitment in the Workplace: Toward a General Model. Human Resource Management Review. 2001; 11: 299-326;Available from: https://doi.org/10 1016/S1053-4822(00)00053-X.

21. Aydin. The Effect of Gender on Organizational Commitment of Teachers: A Meta Analytic Analysis. Educational Sciences: Theory and Practice. 2011; 11(2): 628-632;

22. Mowday RT, Richard MS, Lyman WP. The measurement of organizational commitment. Journal of vocational behavior. 1979; 14(2): 224-247;Available from: https://doi.org/10.1016/ 0001-8791(79)90072-1.

23. Shore T, Shore B. The impact of perceived organizational commitment and leader commitment on organizational citizenship behaviour. International Journal of Organization Theory and Behavior. 2000; 14(2): 145;Available from: https://doi.org/ 10.1108/IJOTB-14-02-2011-B001.

24. Raduan CR, Rajendran M. Typology of organizational commitment. American Journal of Applied Science. 2005; 2(6):1078 1081;Available from: https://doi.org/10.3844/ajassp.2005.1078. 1081.

25. Bhatnagar. Talent management strategy of employee engagement in Indian ITES employees: key to retention. Employee relations. 2007;Available from: https://doi.org/10.1108/ 01425450710826122.

26. Srivastava B. Talent acquisition due diligence leading to high employee engagement: case of Motorola India MDB. Industrial and Commercial Training. 2008;Available from: https:// doi.org/10.1108/00197850810886496.

27. Thompson KR, Luthans F. Organizational culture: A behavioral perspective. In B. Schneider Ed. Organizational climate and culture. San Francisco: Jossey-Bass. 1990; 319-344;. 


\title{
Tác động của văn hóa doanh nghiệp đến cam kết của nhân viên tại ngân hàng Thương mại Cổ phần Sài Gòn Thương Tín tỉnh An Giang
}

\author{
Huỳnh Thanh Tú ${ }^{1,2}$, Trần Minh Hiếu ${ }^{1,2,3}$, Nguyễn Diễm Yến ${ }^{4}$
}

${ }^{1}$ Trường Đại học Kinh tế- Luật, TP Hồ Chí Minh, Việt Nam

${ }^{2} Đ a ̣ i$ học Quốc gia TP Hồ Chí Minh, TP Hồ Chí Minh, Việt Nam

${ }^{3}$ Truơong Đại học An Giang, An Giang, Việt Nam

${ }^{4}$ Ngân Hàng TMCP Sài Gòn Thương Tín, An Giang, Việt Nam

Liên hệ

Trần Minh Hiếu, Trường Đại học Kinh tế Luật, TP Hồ Chí Minh, Việt Nam

Đại học Quốc gia TP Hồ Chí Minh, TP Hồ Chí Minh, Việt Nam

Trường Đại học An Giang, An Giang, Việt Nam

Lịch sử

- Ngày nhận: 19/12/2020

- Ngày chấp nhận: 11/6/2021

- Ngày đăng: 23/6/2021

DOI : $10.32508 /$ stdjelm.v5i3.741

\section{Check for updates}

\section{Bản quyền}

๑ ĐHQG Tp.HCM. Đây là bài báo công bố mở được phát hành theo các điều khoản của the Creative Commons Attribution 4.0 International license.

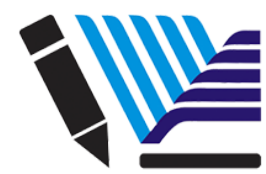

VNU-HCM Press

Trích dẫn bài báo này: Tú H T, Hiếu T M, Yến N D. Tác động của văn hóa doanh nghiệp đến cam kết của nhân viên tại ngân hàng Thương mại Cổ phần Sài Gòn Thương Tín tỉnh An Giang. Sci. Tech. Dev. J. - Eco. Law Manag.; 5(3):1659-1672.

TÓM TẮT

Nghiên cứu này áp dụng thang đo của Ricardo và Jolly năm 1997 để đo lường tác động của văn hóa doanh nghiệp đến cam kết của nhân viên tại Ngân hàng Thương mại cổ phần Sài Gòn Thương Tín Chi nhánh An Giang (Sacombank An Giang). Nghiên cứu sử dụng phương pháp kiểm định độ tin cậy Cronbach's Alpha, phương pháp phân tích nhân tố khám phá (EFA) để kiểm định thang đọ và phương pháp hồi quy để đo lường và đánh giá các yếu tố của văn hoá doanh nghiệp tác động đến cam kết của nhân viên. Hệ số điều chỉnh $R^{2}=0,391$ có nghĩa là 39,1\% sự thay đổi của biến phu thuộc cam kết của nhân viên được giải thích bằng 8 biến độc lập trong mồ hình hôi quy. Bên cạnh đó, $60,9 \%$ sự thay đổi cam kết của nhân viên được giải thích bởi các yếu tố khác chưa được đưa vào mô hình nghiên cứu. Kết quả cho thấy các yếu tố về giao tiếp ngân hàng $(B e t a=0,283)$, làm việc theo nhóm (Beta $=0,260$ ), chấp nhận rủi ro trong đổi mới và sáng tạo (Beta $=0,176)$, sự công bằng và nhất quán trong chính sách quản trị (Beta $=0,163)$, phần thưởng và sự công nhận (Beta $=0,159$ ) và đào tạo và phát triển (Beta $=0,146)$, ảnh hưởng đến sự cam kết của nhân viên tai Sacombank An Giang. Kết quả nghiên cứu sẽ là cơ sở để Sacombank An Giang nhìn nhận các yếu tố ảnh hưởng đến cam kết của nhân viên với ngân hàng, từ đó có kế hoạch nâng cao sự gắn kết của nhân viên, phát triển đội ngũ nhân sự chuyên nghiệp. Đồng thời, nghiên cứu cũng để xuất ý nghĩa quản trị của các yếu tố văn hóa doanh nghiệp đối với cam kết của nhân viên tại Sacombank An Giang. Xây dựng văn hóa doanh nghiệp vững mạnh thực sự nâng cao cam kết của nhân viên và sự phát triển bền vững tại Sacombank Chi nhánh An Giang.

Từ khoá: Cam kết của nhân viên, Văn hoá doanh nghiệp, Sacombank An Giang 